\title{
PENGARUH PERHATIAN ORANGTUA, MOTIVASI BELAJAR, DAN LINGKUNGAN SOSIAL TERHADAP PRESTASI BELAJAR MATEMATIKA SISWA SMP
}

\author{
Didik Kurniawan ${ }^{1)}$, Dhoriva Urwatul Wustqa ${ }^{2)}$ \\ SMP Negeri 20 Mataram NTB ${ }^{1)}$, Universitas Negeri Yogyakarta ${ }^{2)}$ \\ didik0kurniawan@gmail.com ${ }^{1)}$, dhoriva@yahoo.com ${ }^{2)}$
}

\begin{abstract}
Abstrak
Penelitian ini bertujuan untuk mendeskripsikan pengaruh perhatian orangtua, motivasi belajar, dan lingkungan sosial siswa terhadap prestasi belajar matematika siswa kelas VIII SMP di Kota Mataram. Jenis penelitian yang digunakan adalah penelitian kuantitatif yang bersifat expost facto. Populasi dalam penelitian ini adalah siswa kelas VIII SMP Negeri se Kota Mataram pada semester gasal tahun ajaran 2013/2014. Sampel 12 sekolah dipilih dengan menggunakan teknik stratified random sampling berdasarkan tingkat nilai UN sekolah dan mewakili 6 kecamatan yang ada di Kota Mataram dengan jumlah responden sebanyak 364 orang siswa. Instrumen yang digunakan untuk pengambilan data adalah instrumen tes prestasi belajar matematika kelas VIII yang terdiri dari 25 soal, angket perhatian orangtua siswa, angket motivasi belajar, dan angket lingkungan sosial siswa. Hasil penelitian menunjukkan bahwa perhatian orangtua, motivasi belajar dan lingkungan sosial secara bersama-sama memberikan pengaruh yang signifikan terhadap prestasi belajar matematika siswa SMP dengan sumbangan sebesar 10,6\%. Secara parsial perhatian orangtua dan motivasi belajar memberikan pengaruh terhadap prestasi belajar sementara lingkungan sosial tidak memberikan pengaruh terhadap prestasi belajar.
\end{abstract}

Kata kunci: perhatian orangtua, motivasi belajar, lingkungan sosial, dan prestasi belajar matematika

\section{THE EFFECTS OF PARENTAL ATTENTION, LEARNING MOTIVATION, AND SOCIAL ENVIRONMENT, ON MATHEMATICS LEARNING ACHIEVEMENT OF JUNIOR HIGH SCHOOL STUDENTS IN MATARAM}

\begin{abstract}
This study aims to describe the effect of parental attention, learning motivation, and social environment on mathematics achievement of Junior High School Students. This research was a quantitative ex post facto study. The population consisted of grade VIII students of State Junior High Schools in Mataram City in the first semester of academic year 2013/2014. The samples are 12 schools which were selected using stratified random sampling technique based on the level of UN scores representing 6 districts in the city of Mataram with sample size 364. The instrument for data collecting included mathematics achievement test, questionnaires of parental attention, learning motivation, and social environment. The results show that parental attention, learning motivation, and social environment simultaneously have significant effect on mathematics achievement of Junior High school students with contribution 10,6\%, and parental attention and learning the mathematics motivation partially have significant effect on mathematics achievement, while social environment does not have significant effect onmathematics achievement..
\end{abstract}

Keywords: parental attention, learning motivation, social environment, and mathematics learning achievement 


\section{PENDAHULUAN}

Salah satu tujuan dalam peningkatan mutu pembelajaran adalah untuk meningkatkan prestasi belajar siswa. Prestasi belajar mata pelajaran matematika selalu menjadi sorotan tiap tahunnya karena merupakan salah satu dari empat mata pelajaran yang di UN-kan. Dalam mempelajari matematika siswa dituntut untuk memahami konsep, menggunakan penalaran, memecahkan masalah, mengomunikasikan, dan saling menghargai.

Hasil Ujian Nasional (UN) tiga tahun terakhir (2010-2012) menunjukkan perbedaan nilai yang cukup signifikan. Sebagian siswa memperoleh nilai yang sangat baik, namun sebagian lain masih di bawah rata-rata. Perolehan Nilai UN pada tahun 2012 tertinggi adalah 10,00 sedangkan nilai terendah 2,00 sebagaimana yang terlihat pada tabel 1 berikut ini.

Tabel 1. Hasil UN SMP Kota Mataram

\begin{tabular}{cccc}
\hline Tahun Ajaran & $\mathbf{2 0 0 9 / 2 0 1 0}$ & $\mathbf{2 0 1 0 / 2 0 1 1}$ & $\mathbf{2 0 1 1 / 2 0 1 2}$ \\
\hline Jumlah siswa peserta UN & 5688 & 5833 & 5840 \\
Jumlah siswa yang & 1645 & 1130 & 702 \\
memperoleh kurang dari 7,00 & $(28,92 \%)$ & $(19,37 \%)$ & $(12,02 \%)$ \\
Nilai rata-rata & 7,48 & 8,5 & 8,94 \\
Terendah & 1,25 & 2,00 & 2,00 \\
Tertinggi & 10,00 & 10,00 & 10,00 \\
Standar Deviasi & 0,45 & 0,47 & 0,44 \\
\hline
\end{tabular}

Pada kenyataannya berdasarkan tabel nilai UN tersebut masih terdapat perbedaan prestasi belajar yang sangat mencolok. Ada yang memperoleh nilai yang sangat tinggi, namun masih ada juga yang memperoleh nilai yang cukup rendah.

Kota Mataram merupakan satu dari kabupaten/kota yang ada di propinsi NTB. Kota Mataram juga bertindak sebagai ibukota Provinsi NTB. Untuk itu Kota Mataram diharapkan dapat menjadi barometer pendidikan di propinsi NTB. Kota Mataram dengan berbagai fasilitas pendukungnya diharapkan menjadi yang terdepan dalam hal pendidikan dan mampu bersaing dengan kota-kota besar lainnya di Indonesia.

Penduduk Kota Mataram terdiri dari berbagai jenis suku dan agama. Suku asli merupakan suku sasak, diikuti dengan suku Sumbawa, Bima, dan Jawa serta etnis keturunan Arab dengan agama mayoritas adalah Islam. Kemudian ada suku Bali dengan agama Hindunya dan adapula etnis China. Perbedaan suku bangsa dan etnis ini juga berpengaruh pada pola hunian tempat tinggal. Penduduk asli Kota Mataram lebih banyak tinggal pada kampung-kampung sementara pendatang sebagian besar tinggal di perumahan-perumahan. Perbedaan-perbedaan latar belakang ini melahirkan banyak faktor yang diduga dapat mempengaruhi prestasi belajar siswa.

Menurut Slameto (2010, p.54) prestasi belajar dipengaruhi oleh dua macam faktor yaitu faktor intern (bersumber dari dalam diri siswa) dan faktor ekstern (bersumber dari luar siswa).
Faktor intern meliputi faktor jasmaniah, faktor psikologis dan faktor kelelahan, sedangkan faktor ekstern meliputi faktor keluarga, faktor sekolah dan faktor masyarakat.

Di dalam UU Sisdiknas No 20 tahun 2003 Bab IV pasal 7 juga disebutkan bahwa "Orang tua dari anak usia wajib belajar, berkewajiban memberikan pendidikan dasar kepada anaknya". Perhatian orangtua terhadap pendidikan yang dimaksud adalah segala bentuk usaha, dorongan, keterlibatan orangtua dalam kegiatan belajar anak baik di rumah maupun di sekolah. Keterlibatan orangtua dalam memberikan pembimbingan belajar bagi anak dan juga menyediakan fasilitas belajar terutama buku-buku pelajaran serta dorongan untuk lebih menggiatkan anak belajar. Sekolah dan rumah, dalam hal ini orang tua memiliki hubungan yang erat. Hubungan yang positif dapat dipengaruhi oleh jaringan sosial dan kelas sosial orangtua. Jaringan sosial yang dimiliki orangtua dapat mempengaruhi sikap dan kepercayaan terhadap sekolah.

Peneliti telah membuktikan sejak lama bahwa orangtua memberikan pengaruh yang cukup besar bagi prestasi anak-anaknya. Sebagaimana yang dinyatakan oleh Coleman, Bradley, Mayer \& Mclanahan (Tsui, 2005, p.337) "researcher have found that regardless of family income, high parental attention to and effort toward their children's education help raise children's academic achievement". Schenider \& Coleman (Kraaykamp. 2000, p.180) juga menyatakan hal yang serupa bahwa "direct interest and attention of parents for the 
performance of children in school is also an important indicator for the ultimate rich school success" yang bermakna minat dan perhatian orangtua terhadap kinerja anak di sekolah merupakan indikator penting dalam sukses anak di sekola. Keluarga sebagai lembaga pendidikan informal, merupakan lingkungan pendidikan yang pertama dan utama. Keluarga, yang dalam hal ini orangtua memiliki pengaruh terhadap prestasi belajar anaknya (Houtenville \& Conway, 2007, p.1).

Selain faktor keluarga, lingkungan sosial mempunyai peranan dalam prestasi belajar yang diraih siswa. Lingkungan sosial mempunyai peranan dalam prestasi belajar yang diraih siswa. Lingkungan sosial yang dimaksud, yaitu lingkungan masyarakat sekitar tempat tinggal siswa, teman sebaya, dan media baik cetak maupun elektronik. Menurut Barnett \& Casper (2001) "human social environments encompass the immediate physical surroundings, social relationships, and cultural milieus within which defined groups of people function and interact", yang bermakna lingkungan sosial manusia meliputi lingkungan fisik sekitarnya, hubungan sosial dan lingkungan budaya yang didefinisikan sebagai sekelompok orang dengan fungsi tertentu dan saling berinteraksi.

Lingkungan sosial melibatkan kondisi, keadaan dan interaksi antara manusia yang satu dengan yang lainnya. Lingkungan sosial juga mencakup seluruh individu, kelompok, organisasi, dan sistem dimana seseorang berhubungan dengannya. Sebagaimana yang dinyatakan oleh Zastrow \& Kirst-Ashman (1988, p.8) "the social environment also includes all the individuals groups, organization, and system with which a person comes into contact". Demikian halnya dalam proses belajar mengajar, lingkungan merupakan sumber belajar yang banyak berpengaruh terhadap proses pembelajaran yang berlangsung di dalamnya.

Anak berada dalam lingkungan yang berbeda-beda ada yang tinggal di perumahan dengan tingkat masyarakat yang heterogen dan ada pula yang tinggal di kampung dengan masayarakat yang homogen. Perbedaan latar belakang lingkungan anak tersebut dapat mempengaruhi keseharian anak dan persepsinya terhadap pendidikan. Lingkungan masyarakat sekitar tempat tinggal siswa dapat mendukung pendidikan anak bila masyarakat sekitar merupakan orang berpendidikan dan sadar akan pentingnya pendidikan. Sebaliknya siswa yang tinggal di lingkungan dengan masyarakat yang kurang berpendidikan dan tidak sadar akan pentingnya pendidikan, menjadikan mereka menganggap remeh pendidikan, tidak mau bersekolah apalagi belajar.

Lingkungan sosial lainnya yaitu teman sebaya. Teman dapat memberi warna dan mempengaruhi kehidupan siswa. Telah banyak akademisi meneliti bahwa teman sebaya dapat memberikan pengaruh terhadap restasi siswa, tetapi pengaruh yang lebih luas masih menjadi pertanyaan. Siswa bersosialisasi dengan orangorang yang berhubungan dengan mereka melalui interaksi sehari-hari. Teman, sebagaimana orang dewasa dapat memberikan pengaruh yang besar terhadap kehidupan, termasuk di dalamnya prestasi di sekolah. Memahami bagaimana interaksi sosial mempengaruhi prestasi akademik, penting bagi orangtua, pendidik, dan pembuat kebijakan.

Hasil penelitian yang dilakukan Walter \& Bowen (Bowen et al, 2007, p.11) menunjukkan bahwa "peer group acceptance to be indirectly related to academic outcomes, with schoolrelated attitudes and behavior". Penerimaan kelompok teman sebaya secara tidak langsung berhubungan dengan hasil akademik, dengan sikap dan perilaku yang berkaitan dengan sekolah. Santrock (2011, p.82) mengemukakan bahwa "In addition to families and teacher, peers-children of about the same age or maturity level-also play powerful roles in children's development and schooling". Penyataan tersebut bermakna selain orangtua dan sekolah, anak yang memiliki teman sebaya dengan usia yang sama memainkan peranan penting dalam perkembangan dan hal-hal yang berkaitan dengan pendidikan anak di sekolah. Anak yang memiliki teman sebaya juga dapat mempengaruhi motivasi anak dalam belajar.

Selanjutnya, kajian literatur juga menunjukkan bahwa teman sebaya berpengaruh signifikan terhadap semua aspek kehidupan anak termasuk prestasi akademiknya. Hasil penelitian yang dilakukan oleh Gonzales et al. (1996, p.382) menunjukkan bahwa "peer support was positively related to grades for adolesecents living in low risk neghborhoods", dukungan teman sebaya berkaitan secara positif dengan nilai bagi remaja yang tinggal di lingkungan beresiko rendah.

Lingkungan sosial lain yang dapat mempengaruhi siswa ialah media, baik media cetak maupun elektronik. Tidak seperti faktor sosial lain, media massa tidak terlibat interaksi personal secara langsung, interaksi secara teknik berlangsung alami (Berns, 2010, p.54). Remaja 
yang masih dalam tahap perkembangan dan masih mencari jati diri sangat mudah terpengaruh dengan apa yang dibaca dan apa yang dilihat. Remaja juga menyukai hal-hal yang menyenangkan oleh karena itu masih banyak anak dijumpai membolos pada jam sekolah untuk bermain game dan bermain internet di warnet.

Dengan adanya motivasi diharapkan siswa akan lebih giat dalam belajar dan mampu meraih prestasi yang diharapkan. Menurut Schunk (Terjemahan 2012, p.492) "teori motivasi berprestasi berpengaruh bagi pengajaran dan pembelajaran". Schunk et al (2010: 4) juga menambahkan "Motivation is the process whereby goal-directed activity is instigated and sustained". Pernyataan tersebut bermakna motivasi adalah proses dimana kegiatan tujuan diarahkan untuk menghasut/mendorong dan mendukung. Fenomena yang terjadi di sekolah maupun di masyarakat yang terkait dengan motivasi ini antara lain siswa yang telat masuk sekolah, siswa yang rajin datang ke sekolah namun enggan untuk belajar, masih ada siswa yang suka membolos, siswa yang mengantuk di kelas dan lain sebagainya.

Faktor-faktor yang mempengaruhi prestasi belajar yang telah disebutkan sebelumnya belum teridentifikasi dengan baik oleh sekolahsekolah maupun Dinas Pendidikan Kota Mataram. Dengan demikian penelitian ini bertujuan untuk mendeskripsikan pengaruh secara bersama-sama antara perhatian orangtua, motivasi belajar dan lingkungan sosial terhadap prestasi belajar matematika siswa SMP di Kota Mataram. Penelitian ini juga bertujuan untuk mengetahui pengaruh perhatian orangtua, motivasi belajar, dan lingkungan sosial secara parsial terhadap prestasi belajar matematika sisiwa SMP di Kota Mataram.

\section{METODE}

Penelitian ini menggunakan pendekatan kuantitatif dengan jenis penelitian ex-post facto. Penelitian ini dilaksanakan selama bulan November 2013 di sekolah Menengah Pertama Negeri tahun ajaran 2013/2014 se-Kota Mataram Propinsi Nusa Tenggara Barat (NTB). Populasi dalam penelitian ini adalah siswa SMP Negeri kelas VIII se-Kota Mataram tahun pelajaran 2013/2014 yang berjumlah 6007 siswa yang tersebar pada 23 SMP Negeri di Kota Mataram. Ukuran sampel yang digunakan sebanyak 364 orang siswa. Sampel sebanyak 12 sekolah dipilih dengan menggunakan teknik stratified random sampling berdasarkan tingkat nilai UN sekolah dan mewakili 6 kecamatan yang ada di Kota Mataram. Dari 12 sekolah tersebut dipilih masing masing satu kelas VIII secara acak sebagai sampel.

Instrumen yang digunakan dalam penelitian ini adalah angket perhatian orangtua, angket motivasi belajar, angket lingkungan sekolah dan tes prestasi belajar matematika. Pengumpulan data untuk variabel bebas dilakukan dengan cara memberikan angket atau kuesioner kepada siswa kelas VIII SMP. Sedangkan untuk mengukur prestasi belajar matematika peneliti menggunakan nilai tes prestasi belajar yang diperoleh dengan memberikan soal-soal berbentuk pilihan ganda sebanyak 25 butir soal dengan materi semester gasal pada kelas VIII pada mata pelajaran matematika.

Validasi instrumen dalam penelitian ini dilakukan dengan validitas isi dan validitas konstruk. Validitas isi dilakukan dengan meminta bantuan pertimbangan ahli expert judgement. Sementara validitas konstruk dilakukan untuk menguji secara empirik hubungan antar butir soal dan untuk menentukan kelompok soal yang saling menentukan sebagai suatu faktor/ konstruk yang diukur melalui instrumen (Gable, 1986, p.85).

Reliabilitas tes berhubungan dengan kepercayaan dan keajegan hasil tes. Suatu tes dapat dikatakan mempunyai tingkat kepercayaan yang tinggi jika tes tersebut dapat memberikan hasil yang tetap. Untuk bukti reliabilitas instrumen digunakan $\mathrm{Kr}$-20 dan instrumen non tes digunakan pendekatan konsistensi internal (internal consistency approach) dengan alpha Cronbach.

\section{Teknik Analisis Data}

\section{Deskripsi Data}

Untuk data tentang perhatian orangtua, motivasi belajar dan lingkungan sosial siswa dianalisis menjadi data kuantitatif. Selanjutnya skor yang dicapai responden diinterpretasikan dalam 5 kategori menurut Azwar (2010, p.163) seperti dalam tabel berikut: 
Tabel 2. Kriteria Skor Perhatian Orangtua

\begin{tabular}{cc}
\hline Interval skor & Kategori \\
\hline $\bar{X}_{\mathrm{i}}+1,5 \times S B i<x$ & Sangat \\
$\bar{X}_{\mathrm{i}}+0,5 \times S B i<x \leq \bar{X}_{\mathrm{i}}+1,5 \times S B i$ & Tinggi \\
$\bar{X}_{\mathrm{i}}-0,5 \times S B i<x \leq \overline{\mathrm{X}}_{\mathrm{i}}+0,5 \times S B i$ & Tinggi \\
$\overline{\bar{X}}_{\mathrm{i}}-1,5 \times S B i<x \leq \overline{\bar{X}}_{\mathrm{i}}-0,5 \times S B i$ & Sedang \\
$x \leq \bar{X}_{\mathrm{i}}-1,5 \times S B i$ & Rendah \\
& Sangat \\
\hline
\end{tabular}

Pengujian Hipotesis

Untuk pengujian hipotesis yang diajukan maka dalam penelitian ini menggunakan teknik analisis regresi liner berganda dengan 3 variabel bebas dengan model persamaan regresinya adalah sebagai berikut:

$$
Y=\beta_{0}+\beta_{1} X_{1}+\beta_{2} X_{2}+\beta_{3} X_{3}+\varepsilon
$$

Keterangan:

$\mathrm{Y}=$ Pretasi belajar Matematika

$\mathrm{X}_{1}, \mathrm{X}_{2}, \mathrm{X}_{3}=$ Variabel bebas (perhatian orangtua, motivasi belajar, dan lingkungan Sosial) dengan taraf signifikansi 0,05 .

Uji yang digunakan adalah uji $\mathrm{F}$ dengan rumus sebagai berikut:

$F_{\text {hit }}=\frac{\text { MSReg }}{\text { MSRes }}($ Steven. 2009, p.72)

Pada pengujian hipotesis akan dilihat apakah ada pengaruh ketiga variabel bebas secara bersama-sama terhadap variabel terikat. Pengujian selanjutnya akan dilihat apakah ada pengaruh masing-masing variabel bebas terhadap variabel terikat dengan menggunakan uji-t.

t hit $=\frac{b_{\tilde{i}}}{s\left\{b_{i}\right]}$, dengan $s\left\{b_{i}\right\}$ adalah diagonal dari $\mathrm{s}^{2}\{b\}=\operatorname{MSE}\left(X^{\prime} X\right)^{-1}$

Pengujian Asumsi

Dalam penelitian ini digunakan analisis regresi linier berganda. Untuk itu perlu dilakukan pengujian persyaratan analisis yang berupa uji multikolinieritas, uji heterokedastisitas, uji normalitas, dan uji autokorelasi.

Uji linieritas dilakukan untuk melihat apakah spesifikasi model yang digunakan dalam penelitian sebaiknya berbentuk linier, kuadrat atau kubik. Untuk menguji linieritas pada model penelitian ini digunakan uji Lagrange Multiplier bertujuan untuk mendapatkan nilai $\chi^{2}$ hitung atau ( $\left.\mathrm{n} \times \mathrm{R}^{2}\right)$.
Uji multikolinieritas ini dimaksudkan untuk membuktikan atau menguji ada tidaknya hubungan yang linier di antara variabel bebas. Dalam penelitian ini ada 3 variabel bebas yakni perhatian orangtua $\left(\mathrm{X}_{1}\right)$, Motivasi belajar $\left(\mathrm{X}_{2}\right)$, dan lingkungan sekolah $\left(\mathrm{X}_{3}\right)$ yang diduga akan mempengaruhi variabel terikat prestasi belajar matematika (Y). Metode pengujian yang dilakukan menggunakan uji multikolinieritas dengan melihat Variance Inflation Factor (VIF) pada model regresi. Hipotesis yang dalam uji multikolinieritas.

Uji Heterokedastisitas bertujuan menguji apakah dalam model regresi terjadi ketidaksamaan variance dari residual satu pengamatan ke pengamatan yang lain. Untuk mendeteksi ada atau tidaknya heterokedastisitas dapat dilakukan dengan melakukan uji Glejser (Ghozali. 2005, p.143). Yaitu dengan mengabsolutkan nilai residual kemudian melakukan regresi dengan variabel absolut dari residual sebagai variabel terikat dan variabel $\mathrm{X} 1, \mathrm{X} 2$, dan $\mathrm{X} 3$ sebagai variabel bebas. Terdapat Heterokedastisitas apabila variabel bebas mempengaruhi variabel terikat secara independen (Ghozali, 2005, p.144).

Uji normalitas residual bertujuan untuk menguji apakah dalam model regresi, variabel pengganggu atau residual memiliki distribusi normal. Ada dua cara untuk mendeteksi apakah residual berdistribusi normal atau tidak yaitu dengan analisis grafik dan uji statistik". Melalui metode grafik, normalitas dideteksi dengan melihat penyebaran data (titik) pada sumbu diagonal dari grafik atau dengan meligat histogram dari residunya.

Uji autokorelasi ini dilakukan dengan melihat model regresi ganda terdapat masalah autokorelasi atau tidak. Untuk mendeteksi ada atau tidaknya autokorelasi dilakukan dengan melihat grafik plot antara nilai prediksi variabel terikat dengan (dependen) yaitu ZPRED dengan residualnya SRESID.

\section{HASIL DAN PEMBAHASAN}

\section{Deskripsi Hasil Penelitian}

Gambaran mengenai variabel perhatian orang siswa, motivasi belajar siswa, lingkungan sosial dan prestasi belajar matematika siswa dapat dilihat pada tabel 3, 4, 5, 6 dan 7 di bawah ini. 
Tabel 3. Data Statistik Seluruh Variabel Penelitian

\begin{tabular}{lccc}
\hline \multicolumn{1}{c}{ Variabel } & Mean & Median & $\begin{array}{c}\text { Standar } \\
\text { Deviasi }\end{array}$ \\
\hline $\begin{array}{l}\text { Prestasi Belajar } \\
\text { matematika (Y) }\end{array}$ & 50,69 & 48 & 16,03 \\
$\begin{array}{l}\text { Perhatian Orangtua } \\
\text { (X) }\end{array}$ & 74,41 & 74 & 11,33 \\
$\begin{array}{l}\text { Motivasi Belajar } \\
\left(\mathrm{X}_{2}\right)\end{array}$ & 87,86 & 89 & 11,10 \\
$\begin{array}{l}\text { Lingkungan sosial } \\
\text { siswa }\left(\mathrm{X}_{3}\right)\end{array}$ & 89,83 & 90 & 9,08 \\
\hline
\end{tabular}

Variabel Perhatian Orangtua Siswa

Distribusi frekuensi perolehan skor perhatian orangtua siswa disajikan dalam Tabel 4.

Tabel 4. Distribusi Frekuensi Skor Perhatian Orangtua

\begin{tabular}{ccc}
\hline Kategori & Frekuensi & Persentase \\
\hline Sangat Tinggi & 67 & $18,41 \%$ \\
Tinggi & 173 & $47,53 \%$ \\
Cukup & 99 & $27,20 \%$ \\
Rendah & 23 & $6,32 \%$ \\
Sangat Rendah & 2 & $0,55 \%$ \\
Total & 364 & $100 \%$ \\
\hline
\end{tabular}

Berdasarkan Tabel 4 dapat diketahui $18,41 \%$ siswa memiliki tingkat perhatian orang tua yang sangat tinggi, $47,53 \%$ siswa pada kategori tinggi, 27,20\% siswa pada kategori sedang, $6,32 \%$ siswa pada kategori rendah dan $0,55 \%$ siswa memiliki tingkat perhatian orangtua yang sangat rendah. Secara umum perhatian orangtua siswa SMP kelas VIII di kota Mataram termasuk pada kategori tinggi.

Variabel Motivasi Belajar Siswa

Distribusi frekuensi perolehan skor perhatian orangtua siswa disajikan dalam tabel berikut.

Tabel 5. Distribusi Frekuensi Skor Motivasi Belajar

\begin{tabular}{ccc}
\hline Kategori & Frekuensi & Persentase \\
\hline Sangat Tinggi & 129 & $35,44 \%$ \\
Tinggi & 173 & $47,53 \%$ \\
Cukup & 57 & $15,66 \%$ \\
Rendah & 5 & $1,37 \%$ \\
Sangat Rendah & 0 & $0 \%$ \\
\hline
\end{tabular}

Berdasarkan tabel 5 dapat diketahui $35,44 \%$ siswa memiliki tingkat motivasi belajar matematika yang sangat tinggi, $47,53 \%$ siswa pada kategori tinggi, $15,66 \%$ siswa pada kategori sedang, $1,37 \%$ siswa pada kategori rendah dan tidak ada siswa memiliki tingkat motivasi belajar yang sangat rendah. Secara umum motivasi belajar matematika siswa SMP kelas VIII di Kota Mataram termasuk pada kategori tinggi Variabel Lingkungan Sosial Siswa

Distribusi frekuensi perolehan skor lingkungan sosial siswa disajikan dalam tabel 6 berikut.

Tabel 6. Distribusi Frekuensi Skor Lingkungan Sosial Siswa

\begin{tabular}{ccc}
\hline Kategori & Frekuensi & Persentase \\
\hline Sangat baik & 86 & $23,63 \%$ \\
Baik & 223 & $61,26 \%$ \\
sedang & 50 & $13,74 \%$ \\
jelek & 5 & $1,37 \%$ \\
Sangat jelek & 0 & $0,00 \%$ \\
Total & 364 & $100 \%$ \\
\hline
\end{tabular}

Berdasarkan Tabel 6 tersebut dapat diketahui 23,63\% siswa memiliki tingkat lingkungan sosial yang sangat baik, $61,26 \%$ siswa pada kategori baik, $13,74 \%$ orang siswa pada kategori sedang, $1,37 \%$ siswa pada kategori jelek dan $0,27 \%$ siswa berada pada tingkat sangat jelek. Secara umum lingkungan sosial siswa SMP kelas VIII di kota Mataram termasuk pada kategori baik.

\section{Variabel Prestasi Belajar Siswa}

Distribusi frekuensi perolehan skor perhatian orangtua siswa disajikan dalam Tabel 7.

Tabel 7. Distribusi Frekuensi Skor Prestasi Belajar

\begin{tabular}{ccc}
\hline Kategori & Frekuensi & Persentase \\
\hline Sangat tinggi & 35 & $9,62 \%$ \\
tinggi & 78 & $21,43 \%$ \\
sedang & 124 & $34,07 \%$ \\
rendah & 115 & $31,59 \%$ \\
Sangat rendah & 12 & $3,30 \%$ \\
Total & 364 & $100 \%$ \\
\hline
\end{tabular}

Berdasarkan Tabel 7 tersebut dapat diketahui $9,62 \%$ siswa memiliki tingkat prestasi belajar matematika yang sangat tinggi, 21,43\% siswa pada kategori tinggi, 34,07\% siswa pada kategori sedang, $31,59 \%$ siswa pada kategori rendah dan 3,30\% orang siswa berada pada tingkat sangat rendah. Secara umum prestasi belajar matematika siswa SMP kelas VIII di kota Mataram termasuk pada kategori sedang. 


\section{Pengujian Asumsi}

Uji Linieritas

Berdasarkan hasil perhitungan SPSS didapat nilai $\mathrm{R}^{2}$ sebesar 0,013 dengan jumlah responden 364 . Didapatkan besarnya $\chi^{2}$ hitung $=364 \times 0,013=4,732$. Nilai tersebut dibandingkan dengan nilai $\chi^{2}$ tabel dengan $\mathrm{df}=359$ pada tingkat signifikansi 0,05 diperoleh nilai $\chi^{2}$ tabel 394,626. Karena $\chi^{2}$ hitung lebih kecil dari $\chi^{2}$ tabel maka dapat disimpulkan bahwa model yang digunakan adalah model linear.

Uji Multikolinieritas

Hasil nilai VIF dapat dilihat pada tabel 8 .

Tabel 8. Hasil Uji Multikolinieritas

\begin{tabular}{ccc}
\hline Variabel & Tolerance & VIF \\
\hline Perhatian orangtua & 0,635 & 1,576 \\
Motivasi Belajar & 0,621 & 1,610 \\
Lingkungan sosial & 0,604 & 1,656 \\
\hline
\end{tabular}

Berdasarkan Tabel 8 tersebut ternyata masing-masing variabel bebas mempunyai nilai VIF $<10$. Dengan demikian dapat disimpulkan bahwa tidak terdapat multikolinieritas antara variabel bebas.

\section{Uji Heterokedastisitas}

Hasil uji heterokedastisitas menggunakan Uji Glejser. Berdasarkan uji yang telah dilakukan tidak ada satupun variabel independen yang signifikan secara statistik mempengaruhi variabel dependen nilai Absolut Res (ABSRes). Jadi dapat disimpulkan model regresinya tidak mengandung adanya heterokedastisitas.

Uji Normalitas

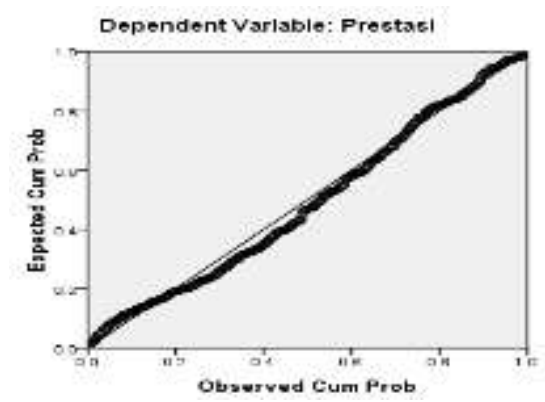

Gambar 1. Hasil Uji Normalitas residual
Uji Normalitas bertujuan untuk mengetahui apakah model regresi, variabel galat atau residual memiliki distribusi normal. Uji normalitas menggunakan bantuan program SPSS 16.0 for Windows dengan hasil seperti pada gambar di atas. Berdasarkan grafik, diketahui bahwa sebaran data yang menyebar di sekitar garis diagonal dan mengikuti arah garis diagonal atau grafik histogramnya menunjukkan pola distribusi normal. Dengan demikian dapat dikatakan bahwa model regresinya memenuhi asumsi normalitas. Didukung pula oleh uji statistik menggunakan uji Kolmogorov-Smirnov diperoleh besarnya nilai Kolmogorv-Smirnov adalah 1,071 dan signifikan pada 0,202 > 0,05 yang artinya data berdistribusi normal.

Uji Autokorelasi

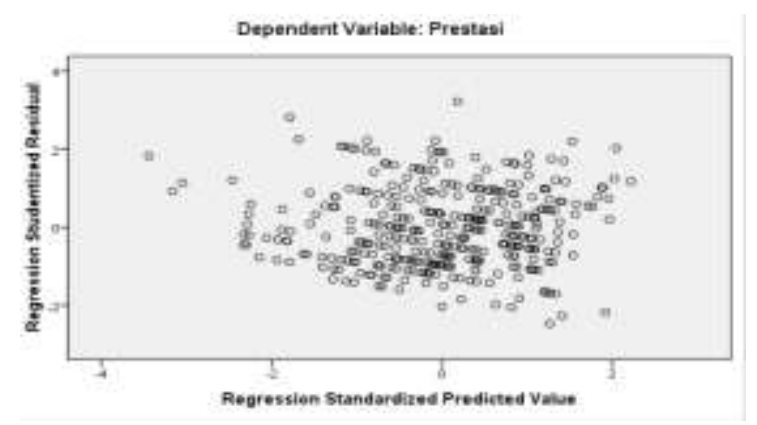

Gambar 2. Hasil Uji Autokorelasi

Berdasarkan Gambar 2 tersebut, terlihat bahwa titik-titik menyebar dan tidak berbentuk pola tertentu. Dengan demikian dapat disimpulkan bahwa tidak terdapat masalah autokorelasi antar variabel.

\section{Pengujian Hipotesis}

Analisis data penelitian ditunjukkan untuk menguji pengaruh perhatian orangtua $\left(\mathrm{X}_{1}\right)$, motivasi belajar $\left(\mathrm{X}_{2}\right)$, dan lingkungan sosial siswa $\left(\mathrm{X}_{3}\right)$ terhadap prestasi belajar matematika (Y) siswa SMP kelas VIII. Untuk menguji hipotesis ini digunakan analisis regresi ganda dengan menempatkan Prestasi belajar matematika sebagai variabel terikat dan perhatian orangtua, motivasi belajar, serta lingkungan sosial siswa sebagai variabel bebas. Rangkuman hasil analisis regresi ganda dapat dilihat pada Tabel 9 di bawah ini. 
Tabel 9. Hasil Uji Anava

\begin{tabular}{cccccc}
\hline Model & Sum of Squares & df & Mean Square & F & Sig. \\
\hline Regression & 9869.62 & 3 & 3289.87 & 14.233 & $.000^{\mathrm{a}}$ \\
Residual & 83212.80 & 360 & 231.15 & & \\
Total & 93082.42 & 363 & & & \\
\hline
\end{tabular}

Berdasarkan Tabel 9 diperoleh nilai uji $\mathrm{F}$ sebesar 14,233 dengan signifikasi $0,000<0,05$ dan berdasarkan kriteria keputusan, $\mathrm{H} 0$ ditolak sehingga dapat disimpulkan bahwa ada pengaruh yang signifikan antara perhatian orangtua (X1), motivasi belajar (X2), dan lingkungan sosial siswa (X3) terhadap prestasi belajar matematika siswa kelas VIII SMP (Y).

Nilai koefisien determinasi $\mathrm{R}^{2}$ yang merupakan besarnya sumbangan ketiga variabel bebas terhadap variabel terikat Y sebesar 0,106, menunjukkan sumbangan dari ketiga variabel bebas sebesar 10,6\% terhadap prestasi belajar matematika siswa kelas VIII SMP di Kota Mataram. Sementara $89,4 \%$ prestasi belajar Siswa SMP kelas VIII dipengaruhi oleh faktor lain.

Untuk melihat pengaruh masing-masing variabel bebas terhadap variabel terikat digunakan uji t. Hasil uji t diperlihatkan pada Tabel 10.

Tabel 10. Hasil Uji Signifikansi Variabel Bebas Secara Parsial

\begin{tabular}{ccccccc}
\hline Model & \multirow{2}{*}{ B } & \multirow{2}{*}{ Beta } & t & Sig. & \multicolumn{2}{c}{ Correlations } \\
\cline { 7 - 8 } & & & & & Parsial & $\mathbf{R}^{2}$ \\
\hline (Constant) & 13,722 & & 1,712 & 0,008 & & \\
Perhatian Orang tua & 0,298 & 0,214 & 3,424 & 0,001 & 0,178 & 0,0317 \\
Motivasi & 0,298 & 0,207 & 3,270 & 0,001 & 0,170 & 0,0289 \\
Lingkungan sosial & $-0,126$ & $-0,075$ & $-1,16$ & 0,245 & $-0,061$ & $-0,004$ \\
\hline
\end{tabular}

Berdasarkan Tabel 10, dari ketiga variabel bebas yang dimasukkan ke dalam model regresi, variabel lingkungan sosial tidak signifikan. Hal ini dapat dilihat dari probabilitas signifikansi untuk lingkungan sosial sebesar 0,245>0,05. Sedangkan variabel perhatian orangtua dan motivasi belajar siswa signifikan pada taraf alpha 0,05. Dari sini dapat dsimpulkan bahwa variabel prestasi belajar siswa dipengaruhi oleh perhatian orangtua dan motivasi belajar dengan persamaan matematis sebagai berikut:

$\mathrm{Y}=13,722+0,298$ Perhatian Orangtua $+0,298$ Motivasi belajar $-0,126$ lingkungan sosial

Berdasarkan persamaan regresi ganda di atas dapat diketahui bahwa konstanta sebesar 13,772 menyatakan jika variabel bebas dianggap konstan, maka rata-rata prestasi belajar siswa sebesar 13,772. Rata-rata skor prestasi belajar meningkat sebesar 0,298 setiap penambahan satu unit perhatian orangtua siswa, atau terdapat penambahan sebesar 0,298 setiap penambahan satu unit motivasi belajar.

Secara parsial besarnya koefisien korelasi masing-masing variabel bebas terhadap prestasi belajar ialah perhatian orangtua menyumbang sebesar 3,17\% dan sumbangan motivasi belajar sebesar $2,89 \%$.

\section{Pembahasan}

Penelitian ini mengungkapkan pengaruh perhatian orangtua, motivasi belajar, dan lingkungan sosial siswa terhadap prestasi belajar siswa pada pelajaran matematika untuk siswa kelas VIII SMP di Kota Mataram. Jumlah responden yang dilibatkan digunakan sebanyak 427 siswa yang tersebar dalam 12 SMP Negeri di kota Mataram semester ganjil tahun pelajaran 2013/2014. Responden diberikan tes prestasi matematika kelas VIII semester I dan angket tentang perhatian orangtua, motivasi belajar siswa, dan lingkungan sosial di sekitar siswa. Dari jumlah responden tersebut data yang kembali sebanyak 399 dan terdapat pula data yang rusak dan tidak lengkap sehingga data yang benarbenar baik dan layak untuk dianalisis sejumlah 364 data.

Berdasarkan data penelitian yang diperoleh, prestasi belajar matematika siswa SMP di Kota Mataram mempunyai rentang skor 20 sampai 100 , dengan nilai rata-rata 50,69, simpangan baku 16,03 dan median 48. Prestasi 
belajar matematika ini diperoleh dari hasil tes matematika kelas VIII semester ganjil yang diberikan kepada siswa. Secara umum nilai siswa masih berada pada kategori sedang dan rendah yaitu sebesar $34,07 \%$ dan $31,59 \%$. Namun terdapat pula siswa yang memiliki prestasi belajar yang termasuk kategori tinggi dan sangat tinggi yaitu sebesar $21,43 \%$ dan $9,62 \%$. Bervariasinya tingkat prestasi belajar matematika yang diraih siswa ini tentu disebabkan oleh banyak hal atau banyak faktor. Beberapa diantaranya yang menjadi perhatian dalam penelitian ini ialah perhatian orangtua, motivasi belajar, dan lingkungan sosial siswa.

Berikut ini akan dibahas beberapa faktorfaktor yang mempengaruhi prestasi belajar matematika berdasarkan hasil penelitian yang telah diperoleh.

Pengaruh Perhatian Orangtua, Motivasi Belajar, dan Lingkungan Sosial Siswa terhadap Prestasi Belajar Matematika Siswa SMP.

Berdasarkan analisa deskriptif secara umum rata-rata perolehan skor masing-masing variabel bebas berada pada kategori tinggi. Ini menunjukkan bahwa siswa SMP di Kota Mataram memiliki tingkat perhatian orangtua dan motivasi belajar yang tinggi, serta lingkungan sosial yang baik yang mampu mendukung dan mempengaruhi prestasi belajar matematika.

Hasil analisa deskriptif dikuatkan oleh hasil uji regresi ganda yang dilakukan. Berdasarkan data yang diperoleh kemudian dilakukan proses regresi ganda untuk memeriksa apakah ada pengaruh ketiga variabel bebas secara serentak terhadap prestasi belajar matematika siswa SMP di Kota Mataram. Setelah dilakukan analisa regresi ganda didapatkan hasil bahwa secara bersama-sama ketiga variabel bebas yaitu perhatian orangtua, motivasi belajar, dan lingkungan sosial siswa memiliki pengaruh yang signifikan terhadap prestasi belajar matematika siswa SMP di kota Mataram tahun pelajaran 2013/2014. Namun dari hasil uji determinasi hanya diperoleh nilai $\mathrm{R}^{2}$ sebesar 0,106 yang berarti bahwa hanya $10,6 \%$ prestasi belajar matematika siswa SMP yang dipengaruhi oleh ketiga variabel bebas tersebut. Sementara sebesar $89,4 \%$ prestasi belajar matematika siswa SMP dipengaruhi oleh faktor lain yang tidak termasuk dalam penelitian ini.
Pengaruh Perhatian Orangtua Siswa terhadap

Prestasi Belajar Matematika Siswa SMP

Berdasarkan analisis deskriptif yang dilakukan, variabel perhatian orangtua siswa berada pada kategori sangat tinggi sebesar $18,41 \%$, tinggi $47,53 \%$, sedang $27,20 \%$, rendah $6,32 \%$ dan sangat rendah sebesar $0,55 \%$. Mayoritas perhatian orangtua siswa berada pada kategori tinggi yaitu sebesar 47,53\%. Rata-rata skor perhatian orangtua siswa sebesar 74,41 yang termasuk pada kategori tinggi. Perhatian orangtua merupakan salah satu faktor yang mendukung anak untuk belajar. Hal ini didukung oleh analisis statistik yang diperoleh.

Berdasarkan hasil regresi ganda yang telah dilakukan secara parsial perhatian orangtua siswa memberikan pengaruh yang signifikan terhadap prestasi belajar siswa. Dari hasil uji t yang dilakukan diperoleh nilai $t$ hitung sebesar 3,424 dengan nilai signifikan $0,001<0,05$ yang berarti bahwa variabel perhatian orangtua memberi pengaruh yang signifikan terhadap prestasi belajar siswa.

Hasil yang diperoleh ini konsisten dengan kajian teori yang dikemukakan bahwa perhatian orangtua memiliki pengaruh positif terhadap prestasi belajar siswa. Sebagaimana yang diungkapkan oleh Houtenville \& Conway (2007, P.1) "...parental effort has strong positive direct effect on student achievement...". Dikuatkan pula oleh Gonzales et al (1996, p.379) yang menemukan bahwa "significant prospective effect of maternal support on adolescent grades" yang bermakna dukungan maternal memiliki pengaruh prospektif yang signifikan terhadap nilai yang diperoleh anak.

Berpengaruhnya perhatian orangtua terhadap prestasi anak pada penelitian ini juga didukung oleh frekuensi siswa yang lebih banyak menjawab sering dan selalu pada penyataanpernyataan yang diajukan pada kuesioner perhatian orangtua. Lima aspek yang merefleksikan variabel perhatian orangtua dijawab siswa dengan lebih banyak menjawab selalu dan sering menunjukkan bahwa besarnya perhatian orang tua terhadap pendidikan dan pengaruhnya terhadap prestasi anak.

Pengaruh Motivasi Belajar Siswa terhadap Prestasi Belajar Matematika Siswa SMP

Berdasarkan analisis deskriptif, motivasi belajar siswa yang menjadi sampel berada pada kategori sangat tinggi $35,44 \%$, kategori tinggi $47,53 \%$, sedang $15,66 \%$, dan rendah $1,37 \%$. 
Mayoritas motivasi belajar siswa berada pada kategori tinggi yaitu sebesar 47,53\%. Nilai ratarata skor motivasi belajar siswa sebesar 87,86 yang juga termasuk pada kategori tinggi. Hal ini menunjukkan bahwa motivasi belajar siswa yang tinggi menjadi salah satu faktor yang berpengaruh terhadap prestasi belajar matematika yang diraih.

Berdasarkan hasil regresi ganda yang telah dilakukan, secara parsial motivasi belajar memiliki pengaruh yang signifikan terhadap prestasi belajar siswa. Sumbangan motivasi belajar terhadap prestasi belajar ditunjukkan oleh koefisien B (pada tabel 10) sebesar 0,298 yang berarti prestasi belajar akan meningkat sebesar 0,298 apabila ada penambahan 1 poin pada motivasi belajar siswa.

Hasil yang diperoleh ini konsisten dengan kajian teori yang dikemukakan bahwa motivasi belajar memiliki pengaruh positif terhadap prestasi belajar siswa. Sebagaimana yang ditemukan oleh peneliti sebelumnya bahwa motivasi belajar memiliki pengaruh yang signifikan terhadap prestasi belajar siswa (Hadiyanti. 2012; Sukati. 2012). Siswa yang memiliki motivasi yang tinggi tampil lebih baik secara akademis dibanding siswa dengan motivasi yang rendah. Sebagaimana yang dinyatakan oleh Tella (2007, p.154) "highly motivated students perform better academically than the lowly motivated students".

Berpengaruhnya motivasi belajar terhadap prestasi anak pada penelitian ini juga didukung oleh lembar kuesioner yang dijawab siswa. Frekuensi siswa yang lebih banyak menjawab sering dan selalu pada penyataan-pernyataan yang diajukan pada kuesioner motivasi belajar baik itu pada pernyataan positif maupun pernyataan negatif. Adanya konsistensi jawaban siswa pada butir pernyataan positif dan butir pernyataan negatif. Tujuh aspek yang merefleksikan variabel motivasi belajar dijawab siswa dengan lebih banyak menjawab selalu dan sering menunjukkan bahwa besarnya motivasi memberikan pengaruh yang besar terhadap prestasi anak.

Pengaruh Lingkungan Sosial Siswa terhadap Prestasi Belajar Matematika Siswa SMP

Berdasarkan analisis deskriptif yang dilakukan, variabel lingkungan sosial siswa berada pada kategori sangat baik sebesar 23,63\%, baik $61,26 \%$, sedang $13,74 \%$, jelek $1,37 \%$ dan sangat jelek sebesar $0,00 \%$. Mayoritas lingkungan sosial siswa berada pada kategori baik yaitu sebesar $61,26 \%$. Rata-rata skor lingkungan sosial siswa sebesar 89,83 yang termasuk pada kategori tinggi.

Berdasarkan hasil regresi ganda yang telah dilakukan, secara bersama-sama dengan variabel bebas lainnya, lingkungan sosial siswa memberikan pengaruh yang signifikan terhadap prestasi belajar siswa. Namun secara parsial berdasarkan uji t yang dilakukan diperoleh $\mathrm{t}$ hitung sebesar -1,165 dengan nilai signifikansi sebesar 0,245 yang nilainya lebih dari 0,05 sehingga dapat dikatakan bahwa dalam penelitian ini lingkungan sosial tidak memberikan pengaruh yang signifikan terhadap presasi belajar matematika siswa.

Hasil yang diperoleh ini kontradiksi dengan kajian teori yang dikemukakan bahwa lingkungan sosial yang di dalamnya termasuk lingkungan masyarakat dan teman sebaya memiliki pengaruh positif terhadap prestasi belajar siswa. Sebagaimana yang ditemukan oleh Gonzales et al (1996, p.382) "peer support was positively related to grades for adolescents living in low risk neighborhoods". Dukungan teman sebaya berkaitan positif dengan nilai pada remaja yang tinggal di lingkungan dengan resiko rendah.

Tidak signifikannya variabel lingkungan sosial juga dapat dilihat dari nilai korelasi partial yang negatif yaitu sebesar -0,061 yang menunjukkan korelasi yang negatif antara lingkungan sosial siswa dengan prestasi belajar. Hasil yang kontradiksi dengan literatur ini juga dapat dicermati dari dua hal, yaitu konstruk angket lingkungan sosial ini sendiri dan jawaban angket oleh siswa.

Bukti validitas isi angket lingkungan sosial yang telah divalidasi oleh ahli menunjukkan bahwa angket layak digunakan. Namun tidak demikian halnya dengan validitas konstruk. Pada awal melakukan analisis faktor ternyata diperoleh nilai KMO yang sangat kecil yaitu 0,149 , dengan banyak butir pertanyaan yang memiliki nilai MSA kurang dari 0,3. Untuk menaikkan nilai KMO menjadi lebih dari 0,5 sehingga layak untuk dianalisis maka butir-butir yang memiliki nilai MSA rendah dibuang sehingga diperoleh hasil instrumen memiliki nilai KMO sebesar 0,545 dengan tiap butir angket memiliki nilai MSA lebih dari 0,3. Rendahnya kualitas instrumen yang dikembangkan mungkin bisa menjadi penyebab tidak signifikannya lingkungan sosial siswa terhadap prestasi belajar siswa.

Berikutnya mencermati jawaban angket siswa pada variabel lingkungan sosial ini dida- 
pati bahwa untuk beberapa butir pertanyaan positif lebih banyak siswa menjawab jarang dan tidak pernah daripada memilih jawaban sering atau selalu. Terkait dengan aspek media yaitu pada butir nomor 29, 30, 33 dan 34 yang merupakan butir pernyataan positif siswa lebih banyak menjawab kadang-kadang, jarang dan tidak pernah dari pada sering dan selalu. Sebaliknya pada butir pernyataan negatif seperti pada nomor 31 dan 32 siswa justru lebih banyak menjawab sering dan selalu. Hal ini mengindikasikan bahwa dalam penelitian ini aspek media baik elektronik maupun cetak tidak memberikan pengaruh yang berarti terhadap prestasi belajar siswa. Dalam hal ini dapat juga berarti bahwa baik siswa yang memiliki prestasi yang baik maupun yang jelek sama-sama tidak menggunakan bantuan media elektronik dan cetak dalam belajar.

Komputer merupakan salah satu media yang biasa digunakan oleh siswa. Menurut Hunley et al (2005, p.307) "the correlation between computer use and grade point was not found to be significant". Menurut penelitian tersebut tidak ditemukan korelasi yang signifikan antara penggunaan komputer dengan nilai yang diperoleh siswa. Temuan Hunley tersebut mendukung hasil pada penelitian ini.

Meskipun dalam penelitian ini lingkungan sosial tidak memberikan pengaruh yang signifikan terhadap prestasi belajar matematika namun aspek lingkungan sekolah menjadi bagian penting dari lingkungan sosial siswa yang mempunyai pengaruh terhadap prestasi siswa. Dalam hal ini relasi antara siswa dengan guru, siswa dengan siswa serta terciptanya ketertiban dan disiplin disekolah dapat menjadi indikator perilaku siswa untuk berprestasi di sekolah. Hal ini didukung oleh penelitian yang dilakukan oleh Nazir \& Matto (2012, p.3) yang mengungkapkan bahwa lingkungan sekolah yang sehat dapat menuntun siswa ke arah performa akademis yang baik dan lingkungan sekolah memiliki peran yang signifikan pada prestasi belajar siswa SMP.

\section{SIMPULAN DAN SARAN}

\section{Simpulan}

Berdasarkan hasil penelitian dan pembahasan hasil penelitian dapat disimpulkan terdapat pengaruh secara bersama-sama perhatian orangtua, motivasi belajar, dan lingkungan sosial siswa terhadap prestasi belajar matematika siswa kelas VIII SMP di Kota Mataram. Besar sumbangan ketiga variabel bebas terhadap prestasi belajar matematika sebesar $10,6 \%$. Dalam penelitian ini juga terdapat pengaruh secara parsial perhatian orangtua terhadap prestasi belajar matematika siswa kelas VIII SMP di Kota Mataram dengan sumbangan parsial sebesar 3,17\% dan pengaruh motivasi belajar terhadap prestasi belajar matematika siswa kelas VIII SMP di Kota Mataram dengan sumbangan parsial sebesar $2,89 \%$. Serta tidak terdapat pengaruh lingkungan sosial terhadap prestasi belajar matematika siswa kelas VIII SMP di Kota Mataram.

\section{Saran}

Berdasarkan hasil penelitian yang diperoleh diketahui bahwa sumbangan perhatian oran gtua siswa, motivasi belajar, dan lingkungan sosial secara bersama terhadapa prestasi belajas siswa SMP di Kota Mataram relatif kecil yaitu $10,6 \%$ maka untuk penelitian sejenis berikutnya perlu melibatkan variabel-variabel lain yang diduga dapat mempengaruhi prestasi belajar siswa. Dalam penelitian ini hanya melibatkan SMP negeri saja sehingga untuk penelitian selanjutnya juga perlu melibatkan sekolah SMP swasta maupun MTS dalam skala yang lebih luas sehingga diperoleh hasil yang lebih baik lagi.

\section{DAFTAR PUSTAKA}

Azwar, Syaifuddin. (2010). Tes prestasi. Yogyakarta: Pustaka Pelajar.

Barnett, E., \& Casper, M. (2001). A definition of social environment. American Journal of Public Health. Diakses pada tanggal 10 Oktober 2013 dari http://www.ncbi.nlm.nih.gov/pmc/article s/PMC1446600/pdf/11249033.pdf.

Berns, R. M. (2010). Child, family, school, community. Wadsworth: Cengage Learning.

Bowen, G.L et al. (2008). Changes in the social environment and the school succes of middle school: A longitudinal Analysis. Diambil pada tanggal 28 Juni 2013dari www.proquest.com.

Gable, R, K. (1986). Instrument development in affective domain. Hingham: Kluwer Academic Publisher

Ghozali, Imam. (2009). Aplikasi analisis multivariate dengan program IBM SPSS 
19. Semarang: Badan penerbit Universitas Diponegoro.

Gonzales, N. A. et al. (1996). Family, peer, and neighborhood influences on academic achievement among African-American adolescents: one year prospective effects. American Journal of Community Psychology, Jun 1996; 24, 3; Proquest (versi elektronik).

Houtenville, A.J. \& Conway, K. S. (2007). Parental Effort, School Resources and Student Achievement. The Journal of Human resources. Vol 43 no. 2 437-453. Diambil pada tanggal 9 april 2013, dari http://jhr.uwpress.org/content/ 43/2/437.refs.

Hunley et al. (2005). Adolescent computer use and academic achievement. Adolescence. 2005; 40, 158. Diambil pada tanggal 12 Juli 2013 dari proquest.com.

Isaac, S. \& Michael, W.B. (1981). Handbook in research and evaluation. San Diego: Edits Publisher.

Kraaykamp, G. (2000). Ouderlijk gezin en schoolsucces. Journal Tijdschrift voor Onderwijsresearch. 2000, 25 p 179-194 [versi elektronik]. Diambil pada tanggal 15 Mei 2013 dari http://gerbertkraaykamp.ruhosting.nl/Pdf_files/2000_TOR. pdf

Nazir, Nasreena \& Matto, Nadhia Hussain. (2012). A Study on impact of school Environment on academic achievement among adolescent. International Journal of Social Science Tomorrow (IJSST). Vol. 1 No. 5 Juli 2012. Diambil pada tangal 22 April 2013 dari www.ijjst.issue.com.611.pdf

Republik Indonesia. (2003). Undang-Undang RI Nomor 20, Tahun 2003, Tentang Sistem Pendidikan Nasional.

Santrock, J.W. (2011). Educational psychology. New York: McGraw Hill.

Schunk, D.H. (2012). Learning theories: an educational perspective (terjemahan Eva Hamdiah \& Rahmat Fajar). Boson:
Pearson Education Inc. (Buku asli diterbikan tahun 2012).

Schunk, D.H., Pintrich P.R., \& Meece, J.L. (2010). Motivation in education. Upper saddle River: Pearson education inc.

Slameto. ( 2010). Belajar dan faktor-faktor yang mempengaruhinya. Jakarta: Rineka Cipta.

Steven, J. P. (2009). Applied multivariate statistics for the social science. New York: Routledge.

Sukati. (2012). Faktor-faktor yang mempengaruhi hasil belajar IPS madrasah Ibtidaiyah siswa kelas $V$ di Kabupaten Bantul Yogyakarta. Tesis Magister, tidak diterbitkan. Universitas Negeri Yogyakarta. Yogyakarta.

Tella, Adedeji. (2007). The impact of motivation on student's academic achievement and learning outcomes in mathematics among secondary school in Nigeria. Eurasia Journal of Mathematics, Science \& Technology Education. 2007, 3(2), 149-156. Diambil pada tanggal 9 Januari 2014 dari http://core.kmi.open.ac.uk/download/ pdf/512292.pdf

Tsui, Ming. (2005). Family income, home environment, parenting, and mathematics achievement of children in China and United States. Journal Education and Urban Society. 2005. 37: 336. Diambil pada tanggal 26 April 2013 dari http://eus.sagepub.com/content/37/3/336

Hadiyanti, Yosefin Rianita. (2012). Pengaruh pola asuh orangtua, motivasi belajar, dan sikap siswa pada pelajaran matematika terhadap prestasi belajar matematika siswa SMP. Tesis Magister, tidak diterbitkan, Universitas Negeri Yogyakarta, Yogyakarta.

Zastrow, C., \& Kirst-Ashman, Karen. (1988). Understanding human behavior and the social environment. Illionis: Nelson Hall Inc. 